\title{
Article \\ Bioactive Fraction of Aronia melanocarpa Fruit Inhibits Adipogenic Differentiation of Cultured 3T3-L1 Cells
}

\author{
Hwa-Young Lee ${ }^{1,2} \mathbb{D}$, Kwang Sik Suh ${ }^{3} \mathbb{D}$, Young Il Kim ${ }^{4} \mathbb{D}$, Bong-Keun Jang ${ }^{5} \mathbb{D}$, Bo-Hyung Kim ${ }^{1,2,6, *(\mathbb{D})}$ \\ and Sung-Vin Yim $2, *$ (D) \\ 1 Department of Biomedical Science and Technology, Graduate School, Kyung Hee University, \\ Seoul 02447, Korea; hy.lee@khu.ac.kr \\ 2 Kyung Hee University Medical Center, Department of Clinical Pharmacology and Therapeutics, \\ Seoul 02447, Korea \\ 3 Department of Endocrinology \& Metabolism, College of Medicine, Kyung Hee University, Seoul 02447, Korea; \\ suhgyber56@naver.com \\ 4 Kyung Hee University Medical Center, Medical Science Research Institute, Seoul 02447, Korea; \\ ewlabkim@khmc.or.kr \\ 5 Research Institute, JBKLAB, 464 Dunchon-daero, Jungwon-gu, Sungnam 13229, Korea; jbk@jbklab.co.kr \\ 6 East-West Medical Research Institute, Kyung Hee University, Seoul 02447, Korea \\ * Correspondence: bhkim98@khu.ac.kr (B.-H.K.); ysvin@khu.ac.kr (S.-V.Y.)
}

check for

updates

Citation: Lee, H.-Y.; Suh, K.S.; Kim, Y.I.; Jang, B.-K.; Kim, B.-H.; Yim, S.-V. Bioactive Fraction of Aronia melanocarpa Fruit Inhibits Adipogenic Differentiation of Cultured 3T3-L1 Cells. Appl. Sci. 2021, 11, 9224. https: //doi.org/10.3390/app11199224

\section{Academic Editors:}

Wojciech Kolanowski and Anna Gramza-Michałowska

Received: 31 August 2021

Accepted: 29 September 2021

Published: 3 October 2021

Publisher's Note: MDPI stays neutral with regard to jurisdictional claims in published maps and institutional affiliations.

Copyright: (c) 2021 by the authors. Licensee MDPI, Basel, Switzerland. This article is an open access article distributed under the terms and conditions of the Creative Commons Attribution (CC BY) license (https:// creativecommons.org/licenses/by/ $4.0 /)$.

\begin{abstract}
Obesity is caused by excessive fat cells and the overgrowth of adipocytes and is a major risk factor for several chronic illnesses. Aronia melanocarpa fruit is rich in anthocyanins and polyphenols and has protective effects against various diseases. In this study, we examined the effect of Aronia extract (Aronia bioactive fraction, $\mathrm{ABF}^{\circledR}$ ) on the biomarkers of the adipogenic pathway during adipocyte differentiation of 3T3-L1 cells. Lipid accumulation was verified by Oil Red O staining. mRNA and protein expression of lipoprotein lipase (LPL), CCAAT/enhancer-binding protein $\alpha(\mathrm{C} / \mathrm{EBP} \alpha)$, peroxisome proliferator-activated receptor $\gamma(\mathrm{PPAR} \gamma)$, fatty acid-binding protein 2 (FABP2), and fatty acid synthase (FAS) were assayed by RT-qPCR and Western blot analyses. Adiponectin and leptin secretion were measured using enzyme-linked immunosorbent assays. $\mathrm{ABF}^{\circledR}$ treatment downregulated lipid accumulation based on Oil Red O staining. $\mathrm{ABF}^{\circledR}$-treated cells exhibited decreased mRNA and protein expression of $\mathrm{LPL}, \mathrm{C} / \mathrm{EBP} \alpha, \operatorname{PPAR} \gamma, \mathrm{FABP} 2$, and FAS. Moreover, $\mathrm{ABF}^{\circledR}$ treatment significantly increased adiponectin secretion and decreased leptin secretion. In conclusion, $\mathrm{ABF}^{\circledR}$ has anti-adipogenic effects on the differentiation of 3T3-L1 cells and may be used as an anti-obesity nutraceutical.
\end{abstract}

Keywords: Aronia melanocarpa fruit; Aronia bioactive fraction $\left(\mathrm{ABF}^{\circledR}\right)$; obesity; 3T3-L1 cells; adipocyte; anti-adipogenesis

\section{Introduction}

Obesity is a major risk factor that is closely related to various pathological conditions and chronic diseases worldwide. According to the World Health Organization (WHO), the prevalence of obesity has nearly tripled since 1975, with over 650 million obese people [1]. Obesity has become a major global public health problem. Excess adiposity is the main cause of obesity and is associated with various diseases, including many cancers, diabetes mellitus, cardiovascular disease, chronic kidney disease, and metabolic syndrome [2-4].

Adipose tissue plays various physiological roles in the secretion of traditional or neuroendocrine hormones, essential energy metabolism, and immune functions $[5,6]$. Adipocytes are also a major player in obesity through their overgrowth and differentiation. Hyperplasia (an increase in cell number) and hypertrophy (an increase in cell size) of adipocytes result in adipose tissue growth. Adipocytes are involved in regulating lipid metabolism and store excessive lipids, triglycerides, free cholesterol, and toxic lipid metabolites in the body $[4,7,8]$. 
3T3-L1 cells are widely used in in vivo studies of adipogenesis and obesity $[9,10]$. During adipocyte differentiation, pre-adipocytes differentiate into mature adipocytes, which are regulated by various transcription factors, such as CCAAT enhancer-binding proteins (C/EBPs) and the peroxisome proliferator-activated receptor (PPAR) [11]. Among these, $\mathrm{C} / \mathrm{EBP} \alpha$ and PPAR $\gamma$ regulate other genes involved in adipogenic pathways, such as fatty acid-binding proteins (FABPs) and lipoprotein lipase (LPL) [12]. In the final stage of adipocyte differentiation (lipid metabolism), fatty acid synthase (FAS) regulates adipocyte differentiation [12-14]. Adipokines (adiponectin and leptin), the final product of lipid metabolism, are involved in various signaling pathways during adipocyte differentiation $[13,14]$. Additionally, lipids accumulate excessively in adipocytes as lipid droplets $[15,16]$.

Aronia melanocarpa is a species of shrub in the Rosaceae family that originates in eastern North America. A. melanocarpa fruit extract $\left(\mathrm{ABF}^{\circledR}\right.$, Aronia bioactive fraction) is one of the most abundant sources of polyphenols and major anthocyanins $[17,18]$. A. melanocarpa fruit is traditionally known for its protective effects against various pathological conditions, such as common colds and inflammation, and is used as a herbal medicine and functional (natural) food $[17,18]$. A. melanocarpa fruit is the main ingredient in juices, jams, wines, and cakes, and is an affluent natural food source $[17,19,20]$. Moreover, previous studies have revealed that $A$. melanocarpa fruit has antioxidant, anticancer, anti-diabetic, anti-inflammatory, cardioprotective, anti-atherosclerotic, and anti-obesity effects $[18,21]$. Various studies (in vivo, in vitro, and clinical studies) have shown that Aronia extracts positively affect human health. In particular, Aronia affects lipid metabolism and fatty acid signaling pathways. Aronia inhibits the total synthesis and absorption of cholesterol and eventually improves lipid metabolism [18,21]. However, there are few studies on the anti-adipogenic effects of $A$. melanocarpa fruit extracts on adipocyte differentiation.

In the present study, we determined whether $A$. melanocarpa fruit extract has inhibitory effects on 3T3-L1 cell differentiation and measured changes in lipid metabolism, various biomarkers, and adipokines.

\section{Materials and Methods}

\subsection{Plant Preparation and HPLC Analysis of $A B F^{\circledR}$}

$\mathrm{ABF}^{\circledR}$ from A. melanocarpa fruit was supplied by JBKLAB (Gyeonggi-do, Korea). ABF ${ }^{\circledR}$ powder was extracted with a $50 \%$ ethanol solution and standardized with an anthocyanin content of approximately $16-18 \%$. $\mathrm{ABF}^{\circledR}$ was dissolved in methanol in $0.5 \%$ trifluoroacetic acid (TFA) and passed through a syringe filter $(0.22 \mu \mathrm{m}$ pore size). The anthocyanin compound in $\mathrm{ABF}^{\circledR}$ was analyzed using a high-performance liquid chromatography-ultraviolet (HPLC-UV) system. Evaluation conditions were applied as described by Oszmianki et al. [22] with slight modifications. HPLC was performed using an Agilent 1200 series (Agilent Technologies, Palo Alto, CA, USA) system, separation was performed using a Zorbax SB C18 $(250 \times 4.6 \mathrm{~mm}, 5 \mu \mathrm{m})$ column (Agilent Technologies) at $25^{\circ} \mathrm{C}$, and the detection wavelength was $520 \mathrm{~nm}$. The gradient elution program used a mobile phase consisting of (A) aqueous $0.5 \%$ TFA and (B) $0.5 \%$ TFA in $50 \%$ acetonitrile. The flow rate was maintained at $1.0 \mathrm{~mL} / \mathrm{min}$, and the injection volume was $20 \mu \mathrm{L}$. The gradient elution system was $18-30 \%$ B for $0-15 \mathrm{~min}, 30 \%$ isocratic for $15-18 \mathrm{~min}$, and $30-50 \%$ B for $18-40 \mathrm{~min}$.

\subsection{Cell Culture and Treatment}

The mouse embryo 3T3-L1 cell line was obtained from the American Type Culture Collection (ATCC, CL173, Manassas, VA, USA). 3T3-L1 pre-adipocytes were cultured in Dulbecco's modified Eagle's medium (DMEM; Life Technologies Co., Carlsbad, CA, USA) containing 10\% ( $v / v)$ fetal bovine serum (FBS, Atlas Biologicals, CO, USA), $100 \mu \mathrm{M}$ ascorbic acid phosphate, $100 \mathrm{U} / \mathrm{mL}$ penicillin, and $100 \mu \mathrm{g} / \mathrm{mL}$ streptomycin, and maintained humidified $5 \%(v / v) \mathrm{CO} 2$ incubator at $37^{\circ} \mathrm{C}$. To differentiate the 3T3-L1 pre-adipocytes into mature adipocytes, after the cells reached the confluence, the cells were incubated in the differentiation medium (MDI cocktail) for 3 days; MDI cocktail contained dexamethasone 
$(1 \mu \mathrm{M})$, 3-isobutyl-1-methylxanthine (0.5 mM, IBMX), and insulin $(10 \mu \mathrm{g} / \mathrm{mL})$ in DMEM (containing 10\% (v/v) FBS and $4.5 \mathrm{~g} / \mathrm{L}$ glucose). To induce adipocyte differentiation, 3T3L1 cells were treated with the $\mathrm{ABF}^{\circledR}$. The cells were then cultured for 2 days in DMEM containing $10 \mu \mathrm{g} / \mathrm{mL}$ insulin and 10\% (v/v) FBS. Finally, they were maintained for an additional 2 days in DMEM containing only 10\% (v/v) FBS [23].

\subsection{Determination of Cell Viability}

Cell viability in $\mathrm{ABF}^{\circledR}$ was measured using the EZ-CYTOX kit (Daeil Lab Service Co., Seoul, South Korea), according to the manufacturer's instructions [23,24]. 3T3-L1 cells were seeded in 24-well plates at a density of $2 \times 10^{4}$ cells/well. After 2 days, the cells were treated with $\mathrm{ABF}^{\circledR}(0.025,0.05,0.1,0.2$, and $0.5 \mathrm{mg} / \mathrm{mL})$ and the vehicle control groups were treated with dimethyl sulfoxide (DMSO). The cells were incubated in a $5 \% \mathrm{CO}_{2}$ at $37^{\circ} \mathrm{C}$ for $48 \mathrm{~h}$. Then, it was treated with the water-soluble tetrazolium (WST) reagent, and incubated for $2 \mathrm{~h}$. Living cells absorbed the WST, which was changed into an orange product. The intensity of color was measured at $450 \mathrm{~nm}$ using a microplate reader (Molecular Devices Emax, Sunnyvale, CA, USA).

\subsection{Oil Red O Staining}

To explore the effects of $\mathrm{ABF}^{\circledR}$ on lipid accumulation in 3T3-L1 adipocytes, lipid accumulation in the cells was measured by Oil Red O staining [23]. Differentiation-induced 3T3-L1 pre-adipocytes were washed with phosphate-buffered saline (PBS, pH 7.4, $135 \mathrm{mM}$ $\mathrm{NaCl}, 2.7 \mathrm{mM} \mathrm{KCl}, 4.3 \mathrm{mM} \mathrm{NaPO}_{4}$, and $1.4 \mathrm{mM} \mathrm{KH}_{2} \mathrm{PO}_{4}$ ) and fixed in $4 \%$ formaldehyde (Junsei, Tokyo, Japan) for $1 \mathrm{~h}$ at room temperature. They were then stained with filtered Oil Red O in $60 \%$ isopropanol for $10 \mathrm{~min}$ at room temperature. The stained cells were washed three times with distilled water and air-dried. Then, the cells were photographed using an inverted microscope. The stained lipid droplets were dissolved in isopropanol and measured at $492 \mathrm{~nm}$ using an enzyme-linked immunosorbent assay (ELISA) reader.

\subsection{RNA Extraction and Reverse Transcription-Quantitative Polymerase Chain Reaction (RT-qPCR)}

Total RNA was extracted from 3T3-L1 cells using the TRIzol reagent (Invitrogen, Carlsbad, CA, USA) following to the manufacturer's instructions. The first-strand and complementary DNA (cDNA) (Thermo Fisher Scientific, Inc.) synthesis were performed with Oligo $(\mathrm{dT})_{15}$ primers and $1 \mu \mathrm{g}$ of total RNA using a reverse transcription system (Thermo Fisher Scientific, Inc.). Primer sequences and product sizes are shown in Table 1. qPCR was conducted in triplicate, the assay was performed on the StepOnePlus Real-Time PCR System with Power SYBR-Green PCR Master Mix (Applied Biosystems; Thermo Fisher Scientific, Inc.). Amplification was performed for each target gene using $1 \mu \mathrm{L}$ of cDNA in a $20 \mu \mathrm{L}$ reaction mixture, consisting of $10 \mu \mathrm{L}$ of Power SYBR Green PCR Master Mix, $2 \mu \mathrm{L}$ of primers, and $7 \mu \mathrm{L}$ of PCR-grade water. The polymerase chain reactions were performed with a denaturation step of 40 cycles at $95^{\circ} \mathrm{C}$ for $10 \mathrm{~min}$, at $95^{\circ} \mathrm{C}$ for $15 \mathrm{~s}$, and at $60^{\circ} \mathrm{C}$ for $1 \mathrm{~min}$. The relationship between the target gene and GAPDH, serving as a housekeeping gene, was determined using the formula $2^{\text {-(target gene-GAPDH) }}$. The relative quantities of transcripts were measured [25].

Table 1. Primer sequences and lengths of amplified templates for reverse transcription-quantitative polymerase chain reaction (RT-qPCR).

\begin{tabular}{|c|c|c|c|c|}
\hline Genes & Accession No. & Forward Primer & Reverse Primer & Product Size $(\mathrm{bp})$ \\
\hline $\mathrm{C} / \mathrm{EBP} \alpha^{1}$ & NM_007678.3 & 5'-AAACAACGCAACGTGGAGA-3' & 5'-GCGGTCATTGTCACTGGTC-3' & 60 \\
\hline $\operatorname{PPAR} \gamma 2^{2}$ & EF062476.1 & $\begin{array}{c}\text { 5'-TTATAGCTGTCATTATTC } \\
\text { TCAGTGGAG-3' }\end{array}$ & 5'-ACTCTGGGTGGTTCAGCTTG-3' & 123 \\
\hline FABP2 ${ }^{3}$ & NM_007980.2 & $5^{\prime}$-ACGGAACGGAGCTCACTG-3' & 5'-TTACCAGAAACCTCTCGGACA-3' & 112 \\
\hline FAS $^{4}$ & NM_007988.3 & 5'- GCTCCTCGCTTGTCGTCT-3' & 5'- GCAACTTCCCCGACATACC-3' & 86 \\
\hline $\mathrm{LPL}^{5}$ & NM_008509.2 & $5^{\prime}$-TTTGTGAAATGCCATGACAAG-3' & 5'-CAGATGCTTTCTTCTCTTGTTTGT-3' & 76 \\
\hline GAPDH & AY618199.1 & 5'-AGGCAAAAGACACCGTCAAG-3' & 5'-CACAAGAAGATGCGGCTGT-3' & 64 \\
\hline
\end{tabular}

${ }^{1} \mathrm{C} / \mathrm{EBP} \alpha, \mathrm{CCAAT} /$ enhancer-binding protein alpha; ${ }^{2} \mathrm{PPAR} \gamma 2$, peroxisome proliferator-activated receptor -gamma $2 ;{ }^{3} \mathrm{FABP} 2$, fatty acid-binding protein $2 ;{ }^{4}$ FAS; fatty acid synthase; and ${ }^{5}$ LPL, lipoprotein lipase. 


\subsection{Immunoblot Analysis}

The primary antibodies and their vendors were as follows: FABP2 (Abcam, Inc., Cambridge, MA), LPL (Santa Cruz Biotechnology, Inc., Santa Cruz, CA, USA), and C/EBP $\alpha$, PPAR $\gamma 2$, and FAS (Cell Signaling Technology, Inc., Danvers, MA, USA). Cells were harvested, washed with cold PBS, and treated with lysis buffer containing $1 \mathrm{mM}$ PMSF (Cell Signaling Technology, Inc.). According to the manufacturer's protocol, protein concentrations were determined using a BCA protein assay (Thermo Fisher Scientific, Inc.) [25]. The protein extracts ( $10 \mu \mathrm{g}$ per lane) were fractionated on $10 \%$ or $12 \%$ sodium dodecyl sulfatepolyacrylamide gel electrophoresis (SDS-PAGE) and transferred onto a nitrocellulose membrane (Amersham Pharmacia Biotech, Inc., Buckinghamshire, UK). The membranes were blocked with $5 \%$ non-fat dry milk in Tris-buffered saline containing $0.1 \%$ Triton-20 (TBS-T) for $1 \mathrm{~h}$ at room temperature under shaking conditions, and then washed with TBS-T for $1 \mathrm{~h}$. The primary antibodies were diluted in 1\% bovine serum albumin (BSA) as following conditions; LPL (1:1000), C/EBP $\alpha$ (1:1000), PPAR $\gamma 2$ (1:1000), FABP2 (1:500), and FAS (1:1000). The membranes were immunoblotted with specific primary antibodies against and incubated at $4{ }^{\circ} \mathrm{C}$ overnight. The following day, secondary antibodies (antirabbit and anti-mouse horseradish peroxidase-conjugated) were diluted to 1:2500 (1:10,000 for $\beta$-actin) in $5 \%$ non-fat dry milk, and the membranes were incubated for $1 \mathrm{~h}$ at room temperature. The membranes were subsequently washed with TBS-T for $1 \mathrm{~h}$, and proteins (reactive band signals) were detected using the Amersham ECL Prime Western Blotting Detection Reagent (GE Healthcare Life Sciences, Piscataway, NJ, USA). Immunoreactive bands were analyzed using an Amersham Imager 600 (GE Healthcare Life Sciences) and were quantified using ImageJ analysis software (ImageJ, version 1.44; National Institutes of Health, Bethesda, MD).

\subsection{Adipokine Secretion Measurement in Cell Supernatant}

Adiponectin and leptin levels in 3T3-L1 cells were measured using a specific sandwich ELISA kits (adiponectin: MBS 2019130 and leptin: MSB: 9717794) purchased from MyBioSource, Inc. (San Diego, CA, USA). 3T3-L1 cells were seeded in 24-well plates at a density of $2 \times 10^{4}$ cells/well and grown to maturation. Afterwards, the media of the cells were homogenized in PBS and centrifuged for $15 \mathrm{~min}$ at $13,000 \times \mathrm{g}$ in $4{ }^{\circ} \mathrm{C}$. The supernatant was then subjected to ELISA. ELISA was performed according to the manufacturer's instructions.

\subsection{Statistical Analysis}

All data were displayed using GraphPad Prism 5 software (GraphPad Software Inc., San Diego, CA, USA) and analyzed using the statistical software SPSS version 23 (IBM Corp., Statistics for Windows, Armonk, NY, USA). The results are presented as mean \pm standard error of the mean (SEM). Statistical significance was determined by one-way analysis of variance and subsequent Dunnett's t-test for multiple comparisons. Statistical significance was determined using $p$-values $\left({ }^{*} p<0.05\right.$ and $\left.{ }^{* *} p<0.01\right)$.

\section{Results}

\subsection{HPLC of Anthocyanins from $A B F^{\circledR}$}

A. melanocarpa fruit contains many bioactive compounds, such as anthocyanins and polyphenols [26]. HPLC analysis was performed at $520 \mathrm{~nm}$ to validate the anthocyanin compounds in the $\mathrm{ABF}^{\circledR}$ extract. Five peaks of ingredients were identified, including four major cyanidin species (Figure 1 ). $\mathrm{ABF}^{\circledR}$ consists mainly of four types of cyanidin: cyanidin3-galactoside (C3Gal, 60.7\%), cyanidin-3-arabinoside (C3Ara, 27.9\%), cyanidin-3-xyloside (C3Xyl, 5.1\%), and cyanidin-3-glucoside(C3Glu4.9\%) (Figure 2). Additionally, the ratio of cyanidin chloride to total anthocyanins was only $1.4 \%$. In $\mathrm{ABF}^{\circledR}$ powder, the total amount of cyanidin and cyanidin glycosides was $17.43 \mathrm{~g} / 100 \mathrm{~g}$, with a content ratio of $17.43 \%$ [27]. 


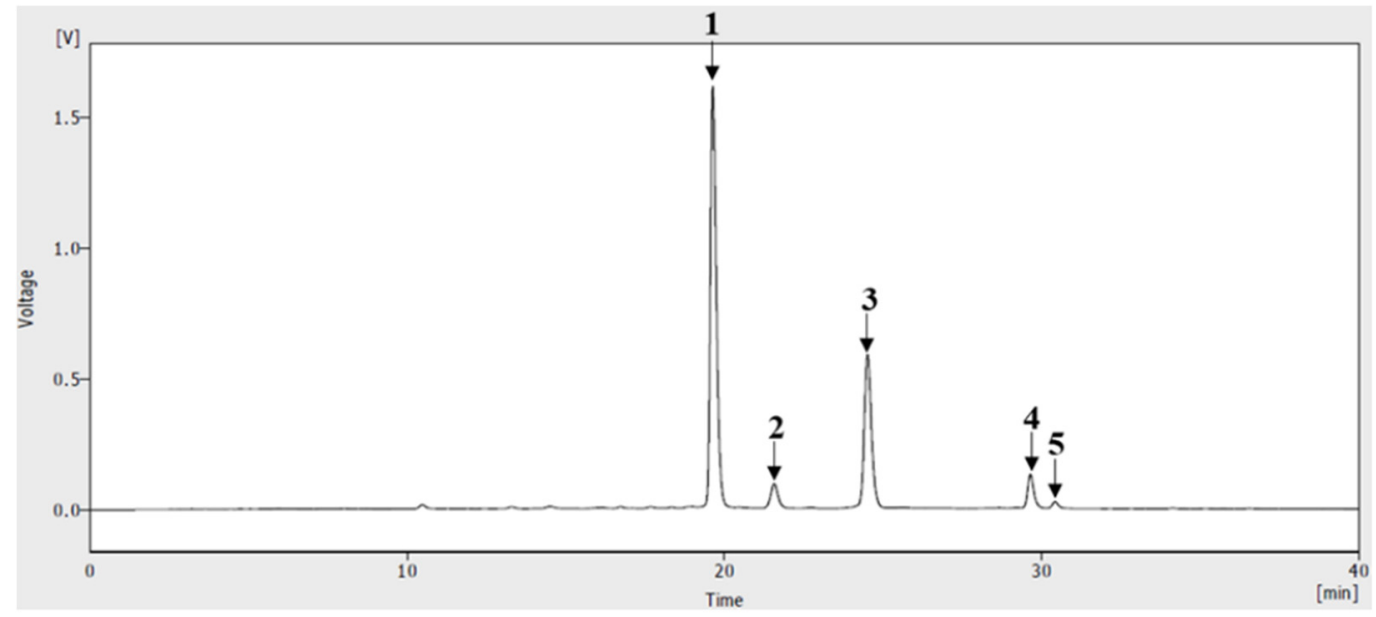

Figure 1. HPLC-UV chromatogram of the Aronia bioactivity fraction $\left(\mathrm{ABF}^{\circledR}\right)$. 1. cyanidin-3-galactoside; 2. cyanidin-3glucoside; 3. cyanidin-3-arabinoside; 4 . cyanidin-3-xyloside; and 5. cyanidin chloride.<smiles>OCC1OC(Oc2cc3c(O)cc(O)cc3[o+]c2-c2ccc(O)c(O)c2)C(O)C(O)C1O</smiles>

1<smiles>OCC1OC(Oc2cc3c(O)cc(O)cc3cc2-c2ccc(O)c(O)c2)C(O)C(O)C1O</smiles>

2<smiles>Oc1cc(O)c2cc(OC3OCC(O)C(O)C3O)c(-c3ccc(O)c(O)c3)cc2c1</smiles>

3<smiles>OC[C@H]1OC(c2cc3c(O)cc(O)cc3cc2-c2ccc(O)c(O)c2)[C@H](O)[C@@H]1O</smiles>

4<smiles>Oc1cc(O)c2cc(O)c(-c3ccc(O)c(O)c3)c(Cl)c2c1</smiles>

5

Figure 2. Chemical structures of compounds from the Aronia bioactivity fraction $\left(\mathrm{ABF}^{\circledR}\right) \mathbf{1}-\mathbf{5}$.

\subsection{Effects of $A B F^{\circledR}$ on Cell Viability of 3T3-L1 Adipocytes}

In this study, 3T3-L1 cells were differentiated into adipocytes, and $\mathrm{ABF}^{\circledR}$ was used to confirm its anti-obesity efficacy, as shown in Figure 3. All analyses were performed after complete differentiation. We first verified the toxicity of $\mathrm{ABF}^{\circledR}$ in $3 \mathrm{~T} 3-\mathrm{L} 1$ cells. Cell viability was measured by treating 3T3-L1 cells with various concentrations of $\mathrm{ABF}^{\circledR}(0.025$, $0.05,0.1,0.2$, and $0.5 \mathrm{mg} / \mathrm{mL}$ ) using EZ-CYTOX kit. The results showed that $\mathrm{ABF}^{\circledR}$ was not toxic to the cells at 0.025 and $0.05 \mathrm{mg} / \mathrm{mL}$ concentrations. However, we found that $\mathrm{ABF}^{\circledR}$ at 0.1 to $0.5 \mathrm{mg} / \mathrm{mL}$ concentrations significantly decreased 3T3-L1 cell viability (Figure 4). Therefore, we performed further experiments using the relatively non-toxic $\mathrm{ABF}^{\circledR}$ concentrations $(0.025$ and $0.05 \mathrm{mg} / \mathrm{mL})$. 


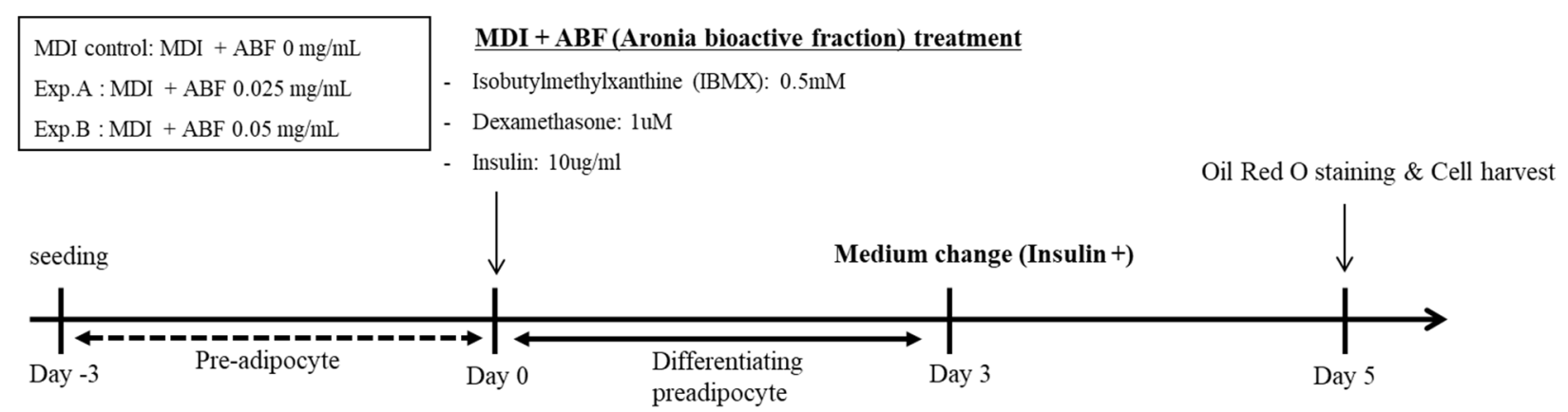

Figure 3. Schematic representation of 3T3-L1 adipocytes differentiation. MDI: 0.5 mM 3-isobutyl-1-methylxanthine, $1 \mu \mathrm{M}$ dexamethasone, and $10 \mu \mathrm{g} / \mathrm{mL}$ insulin. $\mathrm{ABF}^{\circledR}$ : Aronia bioactivity fraction.

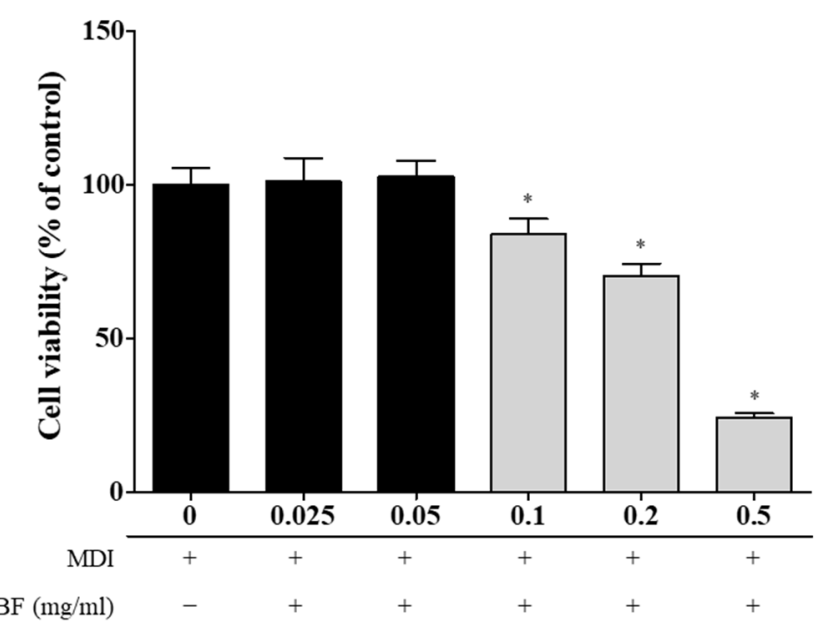

Figure 4. Effects of Aronia bioactive fraction $\left(\mathrm{ABF}^{\circledR}\right)$ on 3T3-L1 adipocyte cell viability. Cell viability was measured in 3T3-L1 cells treated with various concentrations of $\mathrm{ABF}^{\circledR}(0.025,0.05,0.1,0.2$, and $0.5 \mathrm{mg} / \mathrm{mL}$ ) using EZ-CYTOX kit. Data represent the mean \pm SEM. ${ }^{*} p<0.05$ vs. MDI control group $\left(\mathrm{ABF}^{\circledR} 0 \mathrm{mg} / \mathrm{mL}\right)$.

\subsection{Effects of $A B F^{\circledR}$ on Lipid Accumulation in 3T3-L1 Adipocytes}

To explore the effects of $\mathrm{ABF}^{\circledR}$ on lipid accumulation in 3T3-L1 adipocytes, 3T3-L1 cells were treated with $\mathrm{ABF}^{\circledR}$, and lipid accumulation in the cells was measured by Oil Red $\mathrm{O}$ staining. As shown in Figure 5, treatment with $\mathrm{ABF}^{\circledR}(0.025$ and $0.05 \mathrm{mg} / \mathrm{mL})$ significantly decreased oil droplet formation compared with untreated control cells. In particular, the levels of lipid accumulation were significantly reduced by $\mathrm{ABF}^{\circledR} 0.05 \mathrm{mg} / \mathrm{mL}$ relative to that by $\mathrm{ABF}^{\circledR} 0.025 \mathrm{mg} / \mathrm{mL}$ (i.e., it acted in a dose-dependent manner).

\subsection{Effects of $A B F^{\circledR}$ on the $m R N A$ and Protein Expression of Lipoprotein Lipase (LPL) in 3T3-L1 Adipocytes}

We assessed the effects of $\mathrm{ABF}^{\circledR}$ on the mRNA and protein expression of LPL in 3T3-L1 adipocytes. As shown in Figure 6A, the LPL mRNA ratio was significantly reduced in a dose-dependent manner in the 0.025 and $0.05 \mathrm{mg} / \mathrm{mL}$ ( $73 \%$ and $42 \%$, respectively) $\mathrm{ABF}^{\circledR}$ groups compared to the $\mathrm{ABF}^{\circledR}$ non-treatment group (100\%). Additionally, LPL protein expression was significantly decreased in the $\mathrm{ABF}^{\circledR}$ at 0.025 and $0.05 \mathrm{mg} / \mathrm{mL}$ $\left(0.645 \pm 0.039\right.$ and $0.559 \pm 0.080$, respectively) compared to that in the $\mathrm{ABF}^{\circledR}$ non-treatment group $(0.855 \pm 0.062)$ (Figure $6 \mathrm{~B})$. 
(A)

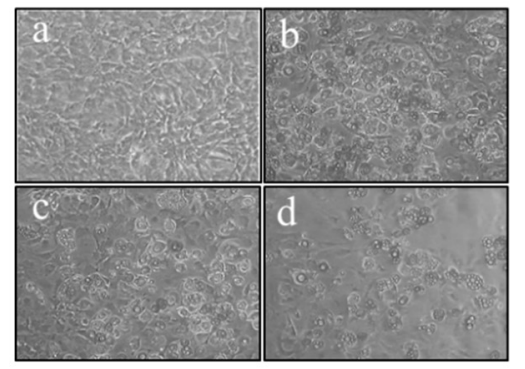

(B)

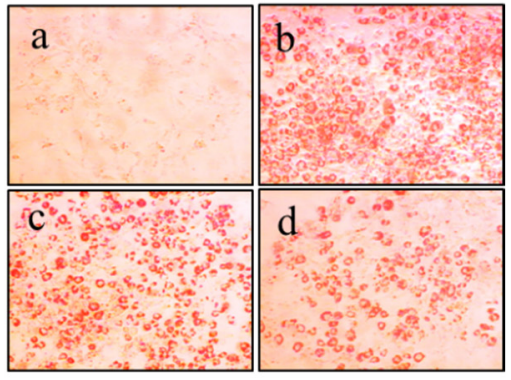

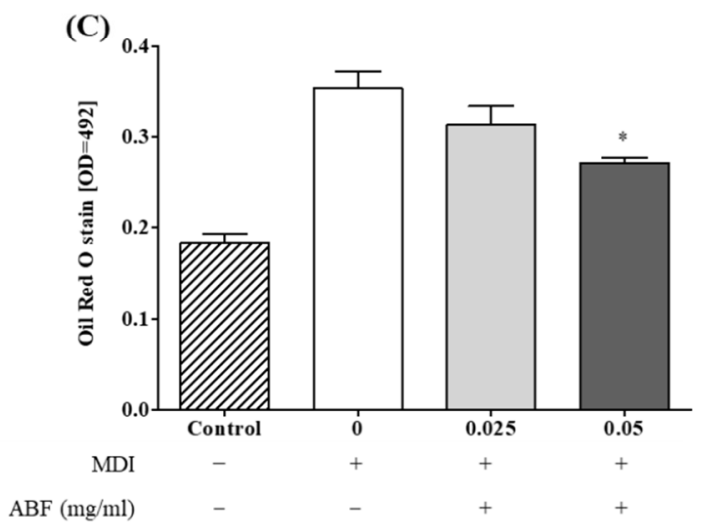

Figure 5. Effects of Aronia bioactive fraction $\left(\mathrm{ABF}^{\circledR}\right)$ on lipid accumulation in 3T3-L1 adipocytes. (A) Lipid accumulation in the cells viewed under an inverted microscope $(100 \times$ magnification) and (B) determined by Oil red O staining. (C) Lipid accumulation measured after Oil Red O elution. (a) 3T3-L1 cells cultured in the non-differentiation medium, (b) adipogenic differentiation medium only (MDI control), (c) adipogenic differentiation medium $+\mathrm{ABF}^{\circledR} 0.025 \mathrm{mg} / \mathrm{mL}$, and (d) and adipogenic differentiation medium $+\mathrm{ABF}^{\circledR} 0.05 \mathrm{mg} / \mathrm{mL}$. Data represent the mean $\pm \mathrm{SEM}$. ${ }^{*} p<0.05$ compared with the MDI control group.

(A)

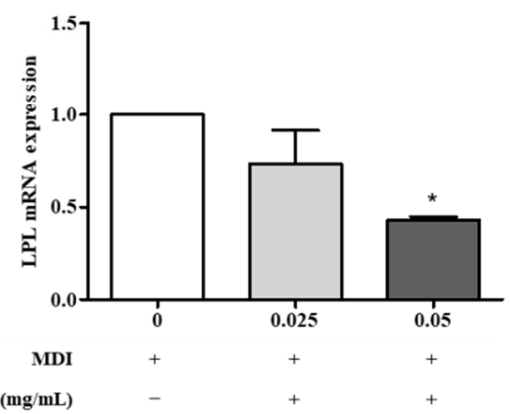

(B)
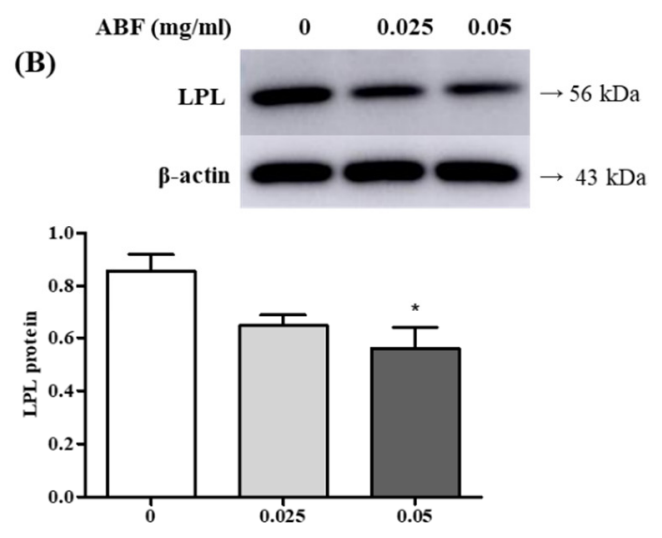

$\begin{array}{rrrr}\mathrm{MDI} & + & + & + \\ \mathrm{ABF}(\mathrm{mg} / \mathrm{mL}) & - & + & +\end{array}$

Figure 6. Effects of lipoprotein lipase (LPL) on the Aronia bioactive fraction $\left(\mathrm{ABF}^{\circledR}\right)$ in $3 \mathrm{~T} 3-\mathrm{L} 1$ adipocytes. 3T3-1 adipocytes were treated with $\mathrm{ABF}^{\circledR}(0.025$ and $0.05 \mathrm{mg} / \mathrm{mL})$. (A) RT-qPCR measured mRNA expression of LPL. ABF ${ }^{\circledR}(0.05 \mathrm{mg} / \mathrm{mL})$ significantly reduced LPL mRNA in 3T3-L1 adipocytes. (B) Protein expression of LPL was measured by Western blot. $\mathrm{ABF}^{\circledR}(0.05 \mathrm{mg} / \mathrm{mL})$ significantly reduced LPL protein in 3T3-L1 adipocytes. Data represent the mean \pm SEM. ${ }^{*} p<0.05$ compared with the MDI control group. 
3.5. Effects of $A B F^{\circledR}$ on the $m R N A$ and Protein Expression of Adipogenesis Levels in 3T3-L1 Adipocytes

We examined the effects of $\mathrm{ABF}^{\circledR}$ on the mRNA and protein expression of adipogenesis levels of $\mathrm{C} / \mathrm{EBP} \alpha, \mathrm{PPAR} \gamma, \mathrm{FABP} 2$, and FAS in 3T3-L1 adipocytes. As shown in Figure 7 , $\mathrm{ABF}^{\circledR}$ reduced the expression of $\mathrm{C} / \mathrm{EBP} \alpha, \mathrm{PPAR} \gamma, \mathrm{FABP} 2$, and FAS in a dose-dependent manner. These results showed that $\mathrm{ABF}^{\circledR}$ has an inhibitory effect on adipocyte production and accumulation by regulating important adipogenic differentiation transcription factors in 3T3-L1 adipocytes.

(A)

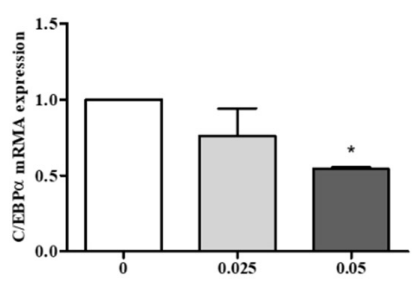

MDI
(B)

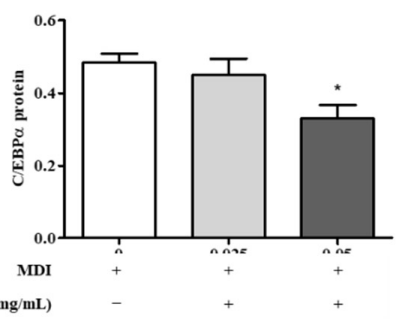

$\begin{array}{llll}\mathrm{ABF}(\mathrm{mg} / \mathrm{ml}) & 0 & 0.025 & 0.05\end{array}$

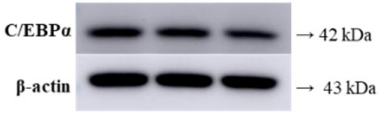

(C)

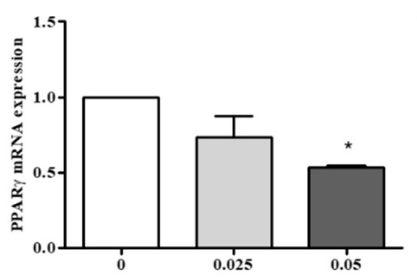

(D)
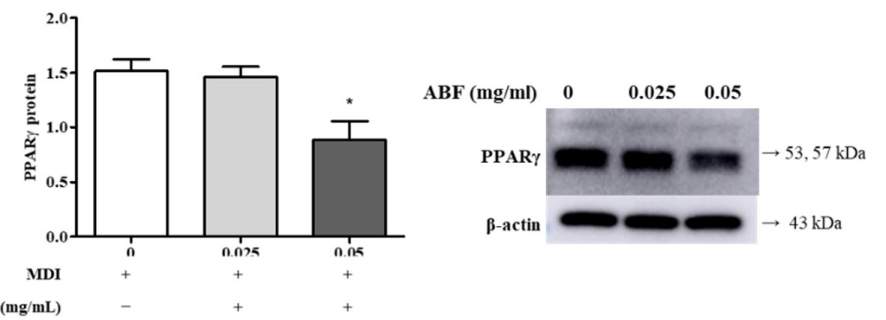

(E)

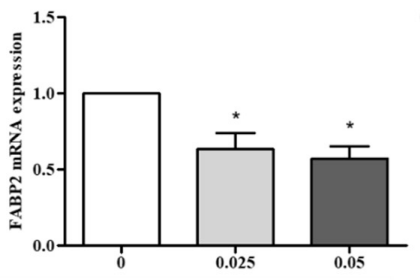

(F)
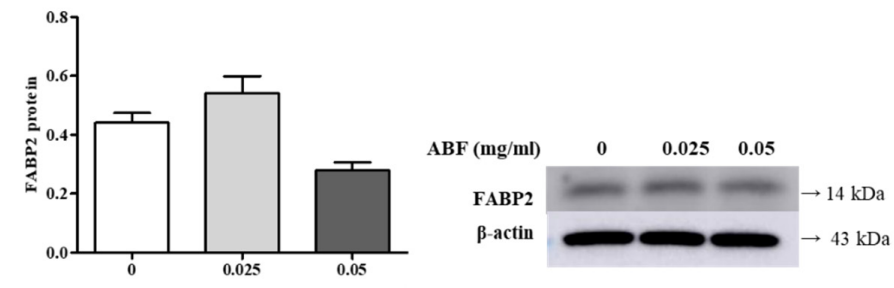

(G)

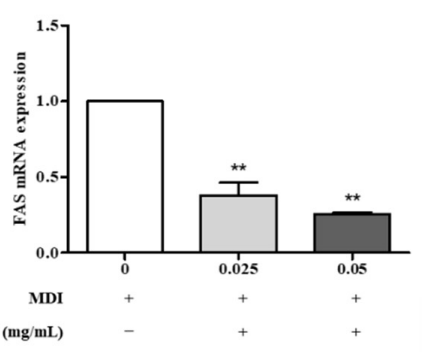

(H)

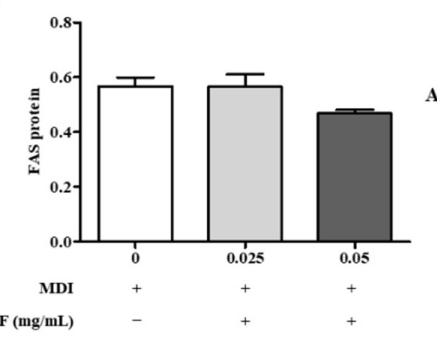

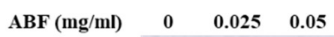

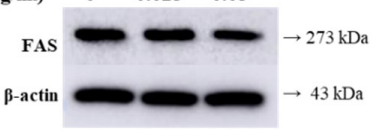

Figure 7. Effects of adipogenesis levels on the Aronia bioactive fraction $\left(\mathrm{ABF}^{\circledR}\right)$ in 3T3-L1 adipocytes. 3T3-1 adipocytes were treated with $\mathrm{ABF}^{\circledR}(0.025$ and $0.05 \mathrm{mg} / \mathrm{mL}) .(\mathbf{A}, \mathbf{B})$ RT-qPCR and Western blot measured mRNA and protein expression of $\mathrm{C} / \mathrm{EBP} \alpha \cdot \mathrm{ABF}^{\circledR}(0.05 \mathrm{mg} / \mathrm{mL})$ significantly reduced $\mathrm{C} / \mathrm{EBP} \alpha$ levels in 3T3-L1 adipocytes. (C,D) RT-qPCR and Western blot measured mRNA and protein expression of PPAR $\gamma \cdot \mathrm{ABF}^{\circledR}(0.05 \mathrm{mg} / \mathrm{mL})$ significantly reduced PPAR $\gamma$ levels in 3T3-L1 adipocytes. (E,F) RT-qPCR and Western blot measured mRNA and protein expression of FABP2. ABF ${ }^{\circledR}(0.05 \mathrm{mg} / \mathrm{mL})$ reduced FABP2 levels in 3T3-L1 adipocytes. $(\mathbf{G}, \mathbf{H})$ RT-qPCR and Western blot measured mRNA and protein expression of FAS. $\mathrm{ABF}^{\circledR}(0.05 \mathrm{mg} / \mathrm{mL})$ significantly reduced FAS levels in 3T3-L1 adipocytes. Data represent the mean $\pm \mathrm{SEM} .{ }^{*} p<0.05$, ** $p<0.001$ compared with the MDI control group. 


\subsection{Effects of $A B F^{\circledR}$ on Adipokine Secretion in 3T3-L1 Adipocytes}

We assessed the effects of $\mathrm{ABF}^{\circledR}$ on adipokine secretion in 3T3-L1 adipocytes. Culture supernatants were collected and used for adipokine secretion analysis. As shown in Figure $8 \mathrm{~A}$, the adiponectin expression was significantly increased in a dose-dependent manner in the 0.025 and $0.05 \mathrm{mg} / \mathrm{mL} \mathrm{ABF}^{\circledR}(709 \pm 31.99,765 \pm 23.58$, respectively) groups compared to that in the $\mathrm{ABF}^{\circledR}$ non-treatment group (582.46 \pm 45.67$)$. Additionally, leptin expression was significantly decreased in the 0.025 and $0.05 \mathrm{mg} / \mathrm{mL} \mathrm{ABF}^{\circledR}$ $\left(525.63 \pm 12.28,509.32 \pm 12.54\right.$, respectively) compared to that in the $\mathrm{ABF}^{\circledR}$ non-treatment group (582.22 \pm 19.54$)$ (Figure 8B).

(A)

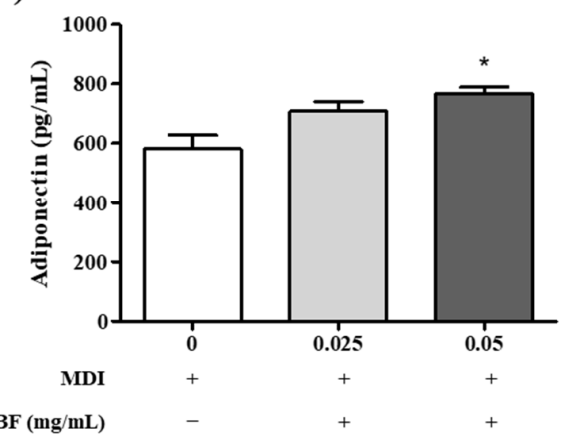

(B)

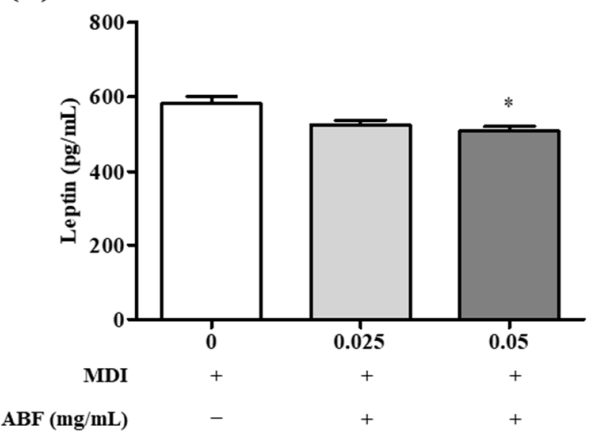

Figure 8. Effects of Aronia bioactive fraction $\left(\mathrm{ABF}^{\circledR}\right)$ on adipokine secretion in 3T3-L1 adipocytes. 3T3-1 adipocytes were treated with $\mathrm{ABF}^{\circledR}(0.025$ and $0.05 \mathrm{mg} / \mathrm{mL})$. (A) Adiponectin significantly increased in $\mathrm{ABF}^{\circledR}(0.05 \mathrm{mg} / \mathrm{mL})$. (B) Leptin significantly decreased in $\mathrm{ABF}^{\circledR}(0.025$ and $0.05 \mathrm{mg} / \mathrm{mL})$. Data represented mean \pm SEM. ${ }^{*} p<0.05$ compared with the MDI control group.

\section{Discussion}

Obesity is a complex multifactorial disease that is closely related to various pathological conditions. Obesity is characterized as abnormal or excessive body fat accumulation due to an energy imbalance between calorie consumption and intake [28]. Hypertrophy and hyperplasia of adipocytes are the main causes of obesity. Several signals are involved in adipogenesis both in vitro and in vivo [8]. Being overweight or obese is defined by the body mass index (BMI). A BMI below 25 is considered normal weight, a BMI of 25 to $<30$ is overweight, and a BMI of 30 or higher indicates obesity [1,29]. As the WHO declared obesity a disease, obese patients need effective treatment. The best way to treat obesity is to exercise regularly and eat healthy foods, such as a low-calorie diet. However, for severe obesity with a BMI greater than 30 , anti-obesity drugs are prescribed to interfere with fat absorption or suppress appetite [30-32]. The Food and Drug Administration (FDA) has approved anti-obesity drugs, such as liraglutide (Saxenda), orlistat (Xenical, Alli), naltrexone-bupropion (Contrave), lorcaserin (Belviq), and phentermine-topiramate (Qsymia) [29,33,34]. However, prescribed anti-obesity drugs have many side effects, such as xerostomia, anorexia, insomnia, and gastrointestinal distress [34,35]. Therefore, recent research on anti-obesity drugs has focused on natural products to reduce the side effects of anti-obesity drugs [36].

A. melanocarpa is a rich source of anthocyanins, polyphenol compounds, and dietary fiber and is well known for its health benefits [21]. Therefore, it has traditionally been widely used as a food ingredient and for treating various diseases due to its antioxidant, anti-inflammatory, anti-diabetic, and anti-obesity effects [18,37]. Natural products are increasingly used to prevent and treat obesity. Additionally, research on natural products is actively focused on bioactive natural compounds with anti-obesity activities [38]. Recently, various studies have been conducted to explore new anti-obesity compounds from natural products $[18,36]$. Therefore, the purpose of this study was to identify whether $A$. melanocarpa fruit extract, $\mathrm{ABF}^{\circledR}$, has the potential to be used as an anti-obesity agent in 3T3-L1 cells. 
We first confirmed the cytotoxicity of $\mathrm{ABF}^{\circledR}$ in 3T3-L1 cells. High doses of $\mathrm{ABF}^{\circledR}(0.1$, 0.2 , and $0.5 \mathrm{mg} / \mathrm{mL}$ ) were cytotoxic to 3T3-L1 adipocytes, and no significant cytotoxicity was detected at $\mathrm{ABF}^{\circledR}$ concentrations of $0.025-0.005 \mathrm{mg} / \mathrm{mL}$. Therefore, concentrations of 0.025 and $0.05 \mathrm{mg} / \mathrm{mL} \mathrm{ABF}^{\circledR}$ were chosen for the following assays.

The effect of $\mathrm{ABF}^{\circledR}$ on lipid accumulation in 3T3-L1 adipocytes was confirmed by Oil Red $\mathrm{O}$ staining (Figure 5). $\mathrm{ABF}^{\circledR}(0.025$ and $0.05 \mathrm{mg} / \mathrm{mL})$ significantly reduced oil droplet formation compared to that in the untreated control cells. These results suggest that adipocyte differentiation was inhibited by the regulation of lipid accumulation in adipocytes by $\mathrm{ABF}^{\circledR}$.

Fatty acids produced by the muscles and liver are stored as triacylglycerols, perform various functions, and are an important energy source [39]. Derangement of fatty acid signaling pathways causes various diseases. Molecules involved in the fatty acid synthesis pathway are targets for the development of anti-obesity drugs and chemicals. Therefore, we assayed fatty acid synthase pathway molecules that secrete LPL, C/EBP $\alpha, \operatorname{PPAR} \gamma$, FABP2, and FAS.

Lipoprotein lipase (LPL) is a member of the lipase gene family, and is usually found on the surface of small blood vessel (capillary) cells in muscle and adipose tissues [40,41]. LPL encodes a lipoprotein lipase expressed in the heart, muscle tissue, and adipose tissue $[7,40]$. Additionally, it plays an important role in breaking down the triglyceride-type fats into fats, and the broken fat molecules are used as energy in the body or stored in adipose tissue [41-43]. In this study, the expression of LPL in 3T3-L1 cells was confirmed by RTqPCR and Western blot analysis (Figure 6). Similar to that reported by Yang et al. [44], the expression of LPL was decreased in a dose-dependent manner in the 0.025 and $0.05 \mathrm{mg} / \mathrm{mL}$ $\mathrm{ABF}^{\circledR}$ groups compared to the $\mathrm{ABF}^{\circledR}$ untreated group.

Lipid accumulation and adipocyte differentiation are major signals in the development of obesity $[15,16]$. Transcription factors that induce gene expression in the adipogenic pathway can differentiate pre-adipocytes into mature adipocytes $[9,10]$. The expression of $\mathrm{C} / \mathrm{EBP} \beta$ is induced in the early stages of 3T3-L1 differentiation and regulates the expression of PPAR $\gamma$ and $\mathrm{C} / \mathrm{EBP} \alpha$, which are major transcription factors of adipogenesis and adipogenesis $[36,45]$. The adipogenic differentiation process is regulated by complex and systematic gene expression, in which CCAAT enhancer-binding protein alpha $(\mathrm{C} / \mathrm{EBP} \alpha)$ and peroxisome proliferator-activated receptor-gamma (PPAR $\gamma$ ) are two major regulators. FABPs are low molecular weight (14-15 kDa) proteins that occur in various tissues. FABP plays an important role in fatty acid metabolism and transport $[39,46,47]$. FABP2 is known to regulate fatty acids and cholesterol during adipocyte differentiation $[48,49]$. FABP2 plays an important role in several long-chain fatty acid transport steps and is associated with increased intestinal fat absorption and obesity [48,50,51]. In the final step, FAS regulates adipocyte differentiation $[6,52,53]$. Therefore, we examined the effects of $A B F^{\circledR}$ on the mRNA and protein expression at adipogenesis levels of $\mathrm{C} / \mathrm{EBP} \alpha, \operatorname{PPAR} \gamma, \mathrm{FABP} 2$, and FAS in 3T3-L1 adipocytes (Figure 7). Similar to the results of a previous study [37,38,54,55], $\mathrm{ABF}^{\circledR}$ inhibited the expression of $\mathrm{C} / \mathrm{EBP} \alpha, \operatorname{PPAR} \gamma, \mathrm{FABP} 2$, and FAS in adipocytes. Thus, it could prevent obesity by blocking early adipocyte differentiation.

Adipose tissue is to express and secrete various peptides, known as adipokines, and express several receptors that can respond to other signals from the hormone system and the central nervous system [5]. Adipose tissue is metabolically active and regulated by energy expenditure through both "nervous and endocrine factors" [56]. Adipokines play an important role in obesity-induced pathophysiological changes at the dysfunctional adipose tissue and cardiometabolic alterations [52,56]. Adiponectin regulates lipid storage and adipogenesis in 3T3-L1 cells [57]. Leptin is produced in adipose tissue and plays an important role in body fat storage associated with food intake, energy homeostasis, and other physiological processes $[14,28]$. We assessed the role of $\mathrm{ABF}^{\circledR}$ in adipokine expression during adipogenesis in 3T3-L1 cells by ELISA (Figure 8). As in the previous study by Katarzyna et al. [58], ABF ${ }^{\circledR}$ treatment of differentiated 3T3-L1 cells significantly enhanced 
adiponectin secretion in adipocytes and decreased leptin secretion in differentiated 3T3-L1 cells in a dose-dependent manner.

These results show that $\mathrm{ABF}^{\circledR}$ has anti-adipogenic potential in 3T3-L1 cells. However, the present study has limitations that should be noted. Firstly, the effects of $\mathrm{ABF}^{\circledR}$ on protein or gene expressions associated with lipolysis, such as adipose triglyceride lipase (ATGL) and hormone-sensitive lipase (HSL), were not examined. As the inhibition of differentiation, as well as inductions of lipolysis, has been focused on therapeutic strategies for treating obesity [59], further studies are necessary to investigate the effects of $\mathrm{ABF}^{\circledR}$ on lipolysis, another important pathway for suppressing fat accumulation. Secondly, our results were obtained in vitro only. It remains to be determined whether the concentrations at which $\mathrm{ABF}^{\circledR}$ exerts beneficial effects are relevant to the concentrations present in vivo. There is a need to progress to well-designed clinical studies in order to validate and further clarify the wide range of applications of $\mathrm{AFB}^{\circledR}$.

\section{Conclusions}

Obesity is a major risk factor, and its prevalence has increased significantly in global populations worldwide. The present study determined whether $A$. melanocarpa fruit extract $\mathrm{ABF}^{\circledR}$ has inhibitory effects on 3T3-L1 cell differentiation and measured changes in lipid metabolism, various biomarkers, and adipokines. Our study showed that $\mathrm{ABF}^{\circledR}$ regulated the biomarkers of the adipogenic pathway during adipocyte differentiation in 3T3-L1 cells. Thus, this study confirmed that $\mathrm{ABF}^{\circledR}$ has anti-adipogenic effects on the differentiation of 3T3-L1 cells and could have anti-obesity effects in functional foods.

Author Contributions: Conceptualization, H.-Y.L., K.S.S., Y.I.K., B.-K.J., B.-H.K. and S.-V.Y.; data curation, B.-H.K.; formal analysis, H.-Y.L., K.S.S., Y.I.K., B.-H.K. and S.-V.Y.; investigation, H.-Y.L., K.S.S., Y.I.K., B.-K.J., B.-H.K. and S.-V.Y.; methodology, H.-Y.L., K.S.S., Y.I.K. and S.-V.Y.; Project administration, B.-H.K. and S.-V.Y.; Supervision, S.-V.Y.; Resources, K.S.S., Y.I.K. and B.-K.J., Validation, H.-Y.L., K.S.S., Y.I.K., B.-H.K. and S.-V.Y.; writing-original draft, H.-Y.L., B.-H.K. and S.-V.Y.; writing-review and editing, H.-Y.L., K.S.S., Y.I.K., B.-H.K. and S.-V.Y. All authors have read and agreed to the published version of the manuscript.

Funding: This research received no external funding.

Institutional Review Board Statement: Not applicable.

Informed Consent Statement: Not applicable.

Data Availability Statement: Not applicable.

Conflicts of Interest: The authors declare no conflict of interest.

\section{References}

1. World Health Organisation. Available online: https://www.who.int/en/news-room/fact-sheets/detail/obesity-and-overweight (accessed on 13 August 2021).

2. De Lorenzo, A.; Romano, L.; Di Renzo, L.; Di Lorenzo, N.; Cenname, G.; Gualtieri, P. Obesity: A preventable, treatable, but relapsing disease. Nutrition 2020, 71, 110615. [CrossRef] [PubMed]

3. Mark, D.H. Deaths attributable to obesity. Jama 2005, 293, 1918-1919. [CrossRef] [PubMed]

4. Ma, S.; Xi, B.; Yang, L.; Sun, J.; Zhao, M.; Bovet, P. Trends in the prevalence of overweight, obesity, and abdominal obesity among Chinese adults between 1993 and 2015. Int. J. Obes. 2021, 45, 427-437. [CrossRef] [PubMed]

5. Kershaw, E.E.; Flier, J.S. Adipose tissue as an endocrine organ. J. Clin. Endocrinol. Metab. 2004, 89, 2548-2556. [CrossRef]

6. Morrison, R.F.; Farmer, S.R. Insights into the transcriptional control of adipocyte differentiation. J. Cell. Biochem. 1999, 75 (Suppl. 32-33), 59-67. [CrossRef]

7. Bays, H.E.; Toth, P.P.; Kris-Etherton, P.M.; Abate, N.; Aronne, L.J.; Brown, W.V.; Gonzalez-Campoy, J.M.; Jones, S.R.; Kumar, R.; La Forge, R.; et al. Obesity, adiposity, and dyslipidemia: A consensus statement from the National Lipid Association. J. Clin. Lipidol. 2013, 7, 304-383. [CrossRef] [PubMed]

8. Ghaben, A.L.; Scherer, P.E. Adipogenesis and metabolic health. Nat. Rev. Mol. Cell Biol. 2019, 20, 242-258. [CrossRef]

9. Zebisch, K.; Voigt, V.; Wabitsch, M.; Brandsch, M. Protocol for effective differentiation of 3T3-L1 cells to adipocytes. Anal. Biochem. 2012, 425, 88-90. [CrossRef] 
10. Student, A.K.; Hsu, R.Y.; Lane, M.D. Induction of fatty acid synthetase synthesis in differentiating 3T3-L1 preadipocytes. J. Biol. Chem. 1980, 255, 4745-4750. [CrossRef]

11. Rosen, E.D.; MacDougald, O.A. Adipocyte differentiation from the inside out. Nat. Rev. Mol. Cell Biol. 2006, 7, 885-896. [CrossRef] [PubMed]

12. Wang, S.; Zhang, Y.; Xu, Q.; Yuan, X.; Dai, W.; Shen, X.; Wang, Z.; Chang, G.; Wang, Z.; Chen, G. The differentiation of preadipocytes and gene expression related to adipogenesis in ducks (Anas platyrhynchos). PLoS ONE 2018, 13, e0196371. [CrossRef] [PubMed]

13. Jakab, J.; Miškić, B.; Mikšić, Š.; Juranić, B.; Ćosić, V.; Schwarz, D.; Včev, A. Adipogenesis as a Potential Anti-Obesity Target: A Review of Pharmacological Treatment and Natural Products. Diabetes Metab. Syndr. Obes. Targets Ther. 2021, 14, 67-83. [CrossRef] [PubMed]

14. Han, M.H.; Kim, H.J.; Jeong, J.W.; Park, C.; Kim, B.W.; Choi, Y.H. Inhibition of Adipocyte Differentiation by Anthocyanins Isolated from the Fruit of Vitis coignetiae Pulliat is Associated with the Activation of AMPK Signaling Pathway. Toxicol. Res. 2018, 34, 13-21. [CrossRef] [PubMed]

15. Ali, A.T.; Hochfeld, W.E.; Myburgh, R.; Pepper, M.S. Adipocyte and adipogenesis. Eur. J. Cell Biol. 2013, 92, 229-236. [CrossRef] [PubMed]

16. Xu, S.; Zhang, X.; Liu, P. Lipid droplet proteins and metabolic diseases. Biochim. Biophys. Acta Mol. Basis Dis. 2018, 1864, 1968-1983. [CrossRef]

17. Valcheva-Kuzmanova, S.V.; Belcheva, A. Current knowledge of Aronia melanocarpa as a medicinal plant. Folia Med. 2006, 48, 11-17.

18. Platonova, E.Y.; Shaposhnikov, M.V.; Lee, H.-Y.; Lee, J.-H.; Min, K.-J.; Moskalev, A. Black chokeberry (Aronia melanocarpa) extracts in terms of geroprotector criteria. Trends Food Sci. Technol. 2021, 114, 570-584. [CrossRef]

19. Kokotkiewicz, A.; Jaremicz, Z.; Luczkiewicz, M. Aronia plants: A review of traditional use, biological activities, and perspectives for modern medicine. J. Med. Food 2010, 13, 255-269. [CrossRef]

20. Slimestad, R.; Torskangerpoll, K.; Nateland, H.S.; Johannessen, T.; Giske, N.H. Analysis. Flavonoids from black chokeberries, Aronia melanocarpa. J. Food Compos. Anal. 2005, 18, 61-68. [CrossRef]

21. Jurendić, T.; Ščetar, M. Aronia melanocarpa Products and By-Products for Health and Nutrition: A Review. Antioxidants 2021, 10, 1052. [CrossRef] [PubMed]

22. Oszmianski, J.; Sapis, J.C. Anthocyanins in fruits of Aronia melanocarpa (chokeberry). J. Food Sci. 1988, 53, 1241-1242. [CrossRef]

23. Choi, E.M.; Suh, K.S.; Jung, W.W.; Park, S.Y.; Chin, S.O.; Rhee, S.Y.; Kim Pak, Y.; Chon, S. Glabridin attenuates antiadipogenic activity induced by 2,3,7,8-tetrachlorodibenzo-p-dioxin in murine 3T3-L1 adipocytes. J. Appl. Toxicol. JAT 2018, 38, $1426-1436$. [CrossRef]

24. Suh, K.S.; Choi, E.M.; Jung, W.W.; Park, S.Y.; Chin, S.O.; Rhee, S.Y.; Pak, Y.K.; Chon, S. 27-Deoxyactein prevents 2,3,7,8tetrachlorodibenzo-p-dioxin-induced cellular damage in MC3T3-E1 osteoblastic cells. J. Environ. Sci. Health Part A 2018, 53, 561-570. [CrossRef]

25. Kim, Y.I.; Lee, C.Y.; Shin, M.K. Downregulation of activin-signaling gene expression in passaged normal human dermal fibroblasts. Biomed. Rep. 2020, 12, 17-22. [CrossRef]

26. Jurikova, T.; Mlcek, J.; Skrovankova, S.; Sumczynski, D.; Sochor, J.; Hlavacova, I.; Snopek, L.; Orsavova, J. Fruits of Black Chokeberry Aronia melanocarpa in the Prevention of Chronic Diseases. Molecules 2017, 22, 944. [CrossRef] [PubMed]

27. Jang, B.K.; Lee, J.W.; Choi, H.; Yim, S.V. Aronia melanocarpa Fruit Bioactive Fraction Attenuates LPS-Induced Inflammatory Response in Human Bronchial Epithelial Cells. Antioxidants 2020, 9, 816. [CrossRef] [PubMed]

28. Karschner, V.A. Post-Transcriptional Regulation of mRNA Metabolism during Differentiation of 3T3-L1 Cells: Role of HuR; East Carolina University: Greenville, NC, USA, 2010.

29. National Institute of Diabetes and Digestive and Kidney Diseases. Available online: https://www.niddk.nih.gov/healthinformation/weight-management/prescription-medications-treat-overweight-obesity (accessed on 13 August 2021).

30. Jensen, M.D.; Ryan, D.H.; Apovian, C.M.; Ard, J.D.; Comuzzie, A.G.; Donato, K.A.; Hu, F.B.; Hubbard, V.S.; Jakicic, J.M.; Kushner, R.F.; et al. 2013 AHA/ACC/TOS guideline for the management of overweight and obesity in adults: A report of the American College of Cardiology / American Heart Association Task Force on Practice Guidelines and The Obesity Society. Circulation 2014, 129, S102-S138. [CrossRef] [PubMed]

31. National Health Information Service. Available online: https://www.nhsinform.scot/illnesses-and-conditions/nutritional/ obesity (accessed on 12 August 2021).

32. University of California San Francisco Health. Available online: https://www.ucsfhealth.org/conditions/obesity/treatment (accessed on 12 August 2021).

33. Derosa, G.; Maffioli, P. Anti-obesity drugs: A review about their effects and their safety. Expert Opin. Drug Saf. 2012, 11, 459-471. [CrossRef]

34. Cheung, B.M.Y.; Cheung, T.T.; Samaranayake, N.R. Safety of antiobesity drugs. Ther. Adv. Drug Saf. 2013, 4, 171-181. [CrossRef]

35. Park, C.H.; Rhyu, D.Y.; Sharma, B.R.; Yokozawa, T. Inhibition of preadipocyte differentiation and lipid accumulation by 7-O-galloyl-d-sedoheptulose treatment in 3T3-L1 adipocytes. Biomed. Prev. Nutr. 2013, 3, 319-324. [CrossRef]

36. Chang, E.; Kim, C.Y. Natural Products and Obesity: A Focus on the Regulation of Mitotic Clonal Expansion during Adipogenesis. Molecules 2019, 24, 1157. [CrossRef] [PubMed] 
37. Kim, N.H.; Jegal, J.; Kim, Y.N.; Heo, J.D.; Rho, J.R.; Yang, M.H.; Jeong, E.J. Chokeberry Extract and Its Active Polyphenols Suppress Adipogenesis in 3T3-L1 Adipocytes and Modulates Fat Accumulation and Insulin Resistance in Diet-Induced Obese Mice. Nutrients 2018, 10, 1734. [CrossRef]

38. Park, M.; Sharma, A.; Lee, H.J. Anti-Adipogenic Effects of Delphinidin-3-O- $\beta$-Glucoside in 3T3-L1 Preadipocytes and Primary White Adipocytes. Molecules 2019, 24, 1848. [CrossRef]

39. Amiri, M.; Yousefnia, S.; Seyed Forootan, F.; Peymani, M.; Ghaedi, K.; Nasr Esfahani, M.H. Diverse roles of fatty acid binding proteins (FABPs) in development and pathogenesis of cancers. Gene 2018, 676, 171-183. [CrossRef]

40. Ordovas, J.M. Genetic influences on blood lipids and cardiovascular disease risk: Tools for primary prevention. Am. J. Clin. Nutr. 2009, 89, 1509S-1517S. [CrossRef] [PubMed]

41. Bouchard, C.; Ordovas, J.M. Recent Advances in Nutrigenetics and Nutrigenomics; Academic Press: London, UK, 2012.

42. Montoudis, A.; Seidman, E.; Boudreau, F.; Beaulieu, J.F.; Menard, D.; Elchebly, M.; Mailhot, G.; Sane, A.T.; Lambert, M.; Delvin, E.; et al. Intestinal fatty acid binding protein regulates mitochondrion beta-oxidation and cholesterol uptake. J. Lipid Res. 2008, 49, 961-972. [CrossRef] [PubMed]

43. Gajda, A.M.; Storch, J. Enterocyte fatty acid-binding proteins (FABPs): Different functions of liver and intestinal FABPs in the intestine. Prostaglandins Leukot. Essent. Fat. Acids 2015, 93, 9-16. [CrossRef] [PubMed]

44. Halldén, G.; Aponte, G.W. Evidence for a role of the gut hormone PYY in the regulation of intestinal fatty acid-binding protein transcripts in differentiated subpopulations of intestinal epithelial cell hybrids. J. Biol. Chem. 1997, 272, 12591-12600. [CrossRef] [PubMed]

45. Rudkowska, I.; Pérusse, L. Individualized weight management: What can be learned from nutrigenomics and nutrigenetics? Progress Mol. Biol. Transl. Sci. 2012, 108, 347-382. [CrossRef]

46. Dave, S.; Kaur, N.J.; Nanduri, R.; Dkhar, H.K.; Kumar, A.; Gupta, P. Inhibition of adipogenesis and induction of apoptosis and lipolysis by stem bromelain in 3T3-L1 adipocytes. PLoS ONE 2012, 7, e30831. [CrossRef]

47. Pirahanchi, Y.; Anoruo, M.; Sharma, S. Biochemistry, Lipoprotein Lipase. In StatPearls; StatPearls Publishing: Treasure Island, FL, USA, 2021.

48. Mead, J.R.; Irvine, S.A.; Ramji, D.P. Lipoprotein lipase: Structure, function, regulation, and role in disease. J. Mol. Med. 2002, 80, 753-769. [CrossRef]

49. MedlinePlus_Lipoprotein Lipase Gene. Available online: https://medlineplus.gov/genetics/gene/lpl/\#conditions (accessed on 13 August 2021).

50. He, Y.; Niu, W.; Xia, C.; Cao, B. Daidzein reduces the proliferation and adiposeness of 3T3-L1 preadipocytes via regulating adipogenic gene expression. J. Funct. Foods 2016, 22, 446-453. [CrossRef]

51. Yao, Y.; Zhu, Y.; Gao, Y.; Shi, Z.; Hu, Y.; Ren, G. Suppressive effects of saponin-enriched extracts from quinoa on 3T3-L1 adipocyte differentiation. Food Funct. 2015, 6, 3282-3290. [CrossRef] [PubMed]

52. Huang, C.; Zhang, Y.; Gong, Z.; Sheng, X.; Li, Z.; Zhang, W.; Qin, Y. Berberine inhibits 3T3-L1 adipocyte differentiation through the PPARgamma pathway. Biochem. Biophys. Res. Commun. 2006, 348, 571-578. [CrossRef] [PubMed]

53. Moseti, D.; Regassa, A.; Kim, W.K. Molecular Regulation of Adipogenesis and Potential Anti-Adipogenic Bioactive Molecules. Int. J. Mol. Sci. 2016, 17, 124. [CrossRef]

54. Farmer, S.R. Transcriptional control of adipocyte formation. Cell Metab. 2006, 4, 263-273. [CrossRef]

55. Freitag Luglio, H. Genetic Variation of Fatty Acid Oxidation and Obesity, A Literature Review. Int. J. Biomed. Sci. IJBS 2016, 12, $1-8$.

56. Khan, M.; Joseph, F. Adipose tissue and adipokines: The association with and application of adipokines in obesity. Scientifica 2014, 2014, 328592. [CrossRef]

57. Stern, J.H.; Rutkowski, J.M.; Scherer, P.E. Adiponectin, Leptin, and Fatty Acids in the Maintenance of Metabolic Homeostasis through Adipose Tissue Crosstalk. Cell Metab. 2016, 23, 770-784. [CrossRef]

58. Kowalska, K.; Olejnik, A.; Szwajgier, D.; Olkowicz, M. Inhibitory activity of chokeberry, bilberry, raspberry and cranberry polyphenol-rich extract towards adipogenesis and oxidative stress in differentiated 3T3-L1 adipose cells. PLoS ONE 2017, 12, e0188583. [CrossRef]

59. Kim, J.H.; Lee, S.; Kim, H.Y.; Cho, E.J. Acer okamotoanum inhibits adipocyte differentiation by the regulation of adipogenesis and lipolysis in 3T3-L1 cells. Int. J. Mol. Med. 2020, 45, 589-596. [CrossRef] [PubMed] 